\title{
Comparing the Learning Approaches of Transfer Students and Direct Entrants in an Asian Higher Education Context
}

\author{
Kin Cheung ${ }^{1, *(\mathbb{D}}$, Ceci Sze Wing Ho ${ }^{1}$, Hilda Tsang ${ }^{1}$ and Elaine Lau ${ }^{2}$ \\ 1 School of Nursing, The Hong Kong Polytechnic University, Hong Kong, China; \\ sze-wing-ceci.ho@polyu.edu.hk (C.S.W.H.); hilda.ht.tsang@polyu.edu.hk (H.T.) \\ 2 Centre for University \& School Partnership (CUSP), Faculty of Education, The Chinese University of \\ Hong Kong, Hong Kong, China; elaine@cuhk.edu.hk \\ * Correspondence: kin.cheung@polyu.edu.hk
}

check for updates

Citation: Cheung, K.; Ho, C.S.W.; Tsang, H.; Lau, E. Comparing the Learning Approaches of Transfer Students and Direct Entrants in an Asian Higher Education Context. Sustainability 2022, 14, 2523. https://doi.org/10.3390/su14052523

Academic Editor: Chung-Ho Su

Received: 9 January 2022

Accepted: 14 February 2022

Published: 22 February 2022

Publisher's Note: MDPI stays neutral with regard to jurisdictional claims in published maps and institutional affiliations.

Copyright: (C) 2022 by the authors. Licensee MDPI, Basel, Switzerland. This article is an open access article distributed under the terms and conditions of the Creative Commons Attribution (CC BY) license (https:// creativecommons.org/licenses/by/ $4.0 /)$.

\begin{abstract}
Transfer students (TSs) transitioning from community college (CC) to university have been found to experience adjustment challenges different from those experienced by direct entrants (DEs) admitted straight from high school, which in turn influences their approaches to learning. Learning can enhance the transition towards sustainability, and it is influenced by various factors. However, there have been limited studies examining the factors associated with TSs' and DEs' learning approaches. To fill this research gap, this current study used a cross-sectional survey with both TSs $(n=841)$ and DEs $(n=978)$ to identify the factors. Our results indicated that the TSs had a higher rate of adoption of surface approaches (SA) to learning than DEs, while TSs and DEs shared some similar predictors of their learning approaches. The results suggest that the commitment of education stakeholders is essential for sustainable learning. They should improve the transfer system by providing adequate support and reduce disparities in the allocation of resources to TSs and DEs, as these affect learning approaches.
\end{abstract}

Keywords: learning approach; community college transfer students; university; variation in learning; transition adjustment

\section{Introduction}

Learning plays an important role in the transition towards sustainability [1]. High school students can be admitted to university through direct entry as direct entrants (DEs) or an alternative " $2+2$ " pathway from community college (CC) as vertical transfer students (TSs) [2]. The surging number of TSs has stimulated interest in research about them, but to date little has been done about their learning approaches. Most TSs experience challenges when adjusting from CC to a new learning environment. For instance, they are likely to experience different teaching styles, approaches, and assessment requirements and a lack of support from their advisors, faculty, and/or peers in the new university [3]. All of these changes may have an impact on their adoption of learning approaches. In fact, possible factors affecting the selection of learning approaches have been investigated. For example, focusing on students enrolled in different disciplines $[4,5]$, previous studies have identified that medical students are generally more adapted to deep approaches (DA) than general education, nursing, and dental students. This revealed that a curriculum with more problem-based activities might be beneficial to enhance DA adaptation. Moreover, previous studies also compared the learning approaches of students from different countries [6,7], and found that Asian students had a higher tendency than Western students to adopt surface approaches (SA), even though both groups of students had similar rates of adoption of DA. This suggests that the different learning environments between different countries might affect students' learning approaches. Some studies have shown that TSs tend to take goal-oriented approaches to their studies in order to fulfil their course requirements [8], but very few have compared directly the learning approaches adopted by TSs and DEs. It 
is useful to identify students' learning approaches to help education stakeholders to design teaching strategies in their curricula [9]. The purpose of our study was to address this gap.

\subsection{Challenges Faced by TSs}

TSs often experience unique challenges such as "transfer shock" (i.e., a disorientation in academic performance and social interactions experienced after transferring to university, leading to a dip in grade point average (GPA)) [10] and "campus culture shock" (i.e., the challenges of adjusting to a new campus environment) [11]. Furthermore, heavy workloads [12], adjustment to a new study and social environment [13,14], and stress [15] are other problems. The heavier workloads could be due to the credits the students have taken at CC not being fully transferrable to their university studies [16], which implies that they will have to take extra modules to fulfil the graduation requirement. On the other hand, TSs strive to develop new social networks during the transition, but feel isolated from the cohort $[14,17,18]$. This might be a reason why TSs are reported to participate less in social events [19] and tend to focus only on striving to cope with the course requirements [8]. These various challenges faced by TSs might have a great impact on their choices of learning approaches.

\subsection{Approaches to Studying and Learning}

Students use various learning approaches within the higher education context [20]. Approaches to studying and learning in general can be categorised into three dimensions: surface, deep, and strategic. A SA is goal-oriented, involves rote learning, and emphasises knowledge memorization without deep understanding. Students who use SAs tend to reproduce the knowledge and focus on coping with the assessment demands and merely fulfilling the academic requirements (e.g., passing the examination). In contrast, a DA involves meaningful learning and focuses on understanding, relating, and evaluating knowledge. Students who use DAs tend to seek to understand the meaning of the content and construct knowledge out of what they study. A strategic approach is defined as using time and space effectively to study. Students using strategic approaches tend to organise their learning according to the assessment requirements (i.e., aiming to maximise their own grades) [21,22]. A surface learning approach has been considered to inhibit learning sustainability as the knowledge learnt cannot be sustained for future endeavours [23,24]. Furthermore, learning approaches were found correlated with sustainable behaviours [25]. Previous studies found that factors affecting students' approaches to studying and learning have been investigated widely. They summarised three main factors influencing students' choices: (1) contextual factors; (2) perceived contextual factors; and (3) student factors [26-28].

Contextual factors are the properties that define the study context, such as characteristics of assessment and teaching methods, characteristics of the teacher (quality, style, or personality), feedback from the teacher, study content, and teacher-student interactivity [26]. For instance, researchers have reported that problem-based curricula encourage students to use DA and reduce their use of SA more than subject-based curricula. Problembased learning is a student-centred instructional approach which is designed to encourage students to self-study and engage in discussions with peers and teachers in order to enhance their knowledge integration and skills [29]. Perceived contextual factors relate to how students perceive their learning environments. These factors include their perceptions of the teaching and support received from teachers and the institution, and in particular of the workload, which has been shown to be a critical factor affecting learning approaches [30-33]. The perception that their workloads are acceptable can increase students' adoption of DA, while the reverse also applies [31,32]. Student-related factors such as age, gender, personality, motivation, and intellectual ability also contribute to determining their learning approaches. For instance, mature females have a higher tendency than young males to adopt DAs, because most of them are intrinsically motivated to study and more satisfied with their degree experiences than younger male students $[34,35]$. 


\subsection{Purpose of the Study}

As discussed, the choice of a learning approach is determined by various factors, and this indicates how students perceive and respond to their learning environments [36]. In the university transfer system, TSs and DEs have different entry pathways to university. However, there have not been any studies comparing the learning approaches of TSs and DEs or examining the factors associated with their choices of learning approaches. Thus, the aim of this study was to address these gaps by investigating the hypotheses that: (1) TSs and DEs would have different learning approaches; and (2) the factors predicting the learning approaches would be different for the two groups of students.

\section{Methods}

\subsection{Research Design}

This study used a cross-sectional online survey with convenience sampling. The data were collected in a Hong Kong university from April to November 2018. All participants were full-time government-funded undergraduate students and recruited through emails, posters, and in-class promotion. The target participants were local DEs and TSs; international and postgraduate students were therefore excluded from the study. The study protocol was approved by the institutional review board (approval number: HSEARS2018004005-01).

\subsection{Instrument}

A battery of questionnaires was used that included the HowULearn Questionnaire [37], Hong Kong Modified Laanan-Transfer Student Questionnaire (HKML-TSQ) [38], the Depression Anxiety Stress Scale (DASS), and Academic Locus of Control (ALC). Demographic information was also collected, including age, gender, and type of student (TS or DE). The reliability of the questionnaire battery was established in previous studies $[12,39]$. (See Appendix A for the questionnaire battery).

The HowULearn questionnaire consisted of five sections: (i) learning approaches (12 items) (deep approach (8 items, Cronbach's $\alpha=0.84)$ and surface approach (4 items, $\alpha=0.71)$ ); (ii) teaching and learning environment (21 items) (teaching for understanding and encouraging learning (11 items, $\alpha=0.92$ ); peer support ( 3 items, $\alpha=0.77$ ); and alignment and constructive feedback ( 7 items, $\alpha=0.89)$ ); (iii) self-efficacy beliefs ( 5 items, $\alpha=0.86$ ); (iv) study workload ( 3 items, $\alpha=0.78$ ); and (v) general working life skills ( 7 items, $\alpha=0.88)[12]$.

The HKML-TSQ was composed of: (i) perceived disparity of TSs and DEs (8 items) 9 resources and stigma (4 items, $\alpha=0.80$ ), and academic study ( 4 items, $\alpha=0.75)$ ); (ii) university support (20 items) (general support and advising (10 items, $\alpha=0.90$ ); academic experience and advising ( 6 items, $\alpha=0.86$ ); and institutional attributes ( 4 items, $\alpha=0.73)$ ); and (iii) coping style at the university (15 items) (avoidance (4 items, $\alpha=0.88$ ), emotional ( 3 items, $\alpha=0.77$ ); active (6 items, $\alpha=0.81$ ); and escape ( 3 items, $\alpha=0.74$ ) [39].

A total of 21 items from the Depression Anxiety Stress Scale (DASS) [40] and 28 items on ALC [41] (28 items) were also used. The Cronbach's $\alpha$ coefficients for depression ( 7 items), anxiety ( 7 items), stress ( 7 items) and ALC were $0.89,0.88,0.89$, and 0.52 , respectively. Due to the low Cronbach's $\alpha$, ALC scores were adjusted by deleting items with low loading factors. The modified ALC consisted of 18 items with Cronbach's $\alpha=0.72$.

The participants were asked to indicate their agreement with each item on a 5-point Likert scale $(1=$ strongly disagree and $5=$ strongly agree $)$, apart from the items on university support and DASS, which used a 4-point Likert scale (university support: $1=$ very dissatisfied and $4=$ very satisfied; DASS: $0=$ did not apply to me at all and $3=$ applied to me very much, or most of the time). The items on ALC were measured by a 2-point Likert scale $(1=$ True and $2=$ False $)$, with the total scores of this factor calculated by setting "True" as 1 and "False" as 0 . 


\subsection{Data Analysis}

All data were analysed using SAS Version 9.4 for the Windows platform (SAS Institute Inc., Cary, NC, USA), and the PROC GLMSELECT procedure was used for the linear regression analyses. The Mann-Whitney $U$ test was used to identify differences between TSs and DEs with regard to age, GPA, and the scores for the study variables. Spearman's correlation $\left(r_{s}\right)$ test was used to test the correlations between the scales of the items for each factor. Variables with statistically significant correlations with the learning approach were selected for the linear regression analysis (forward) to determine the predicting factors. In all cases, $p<0.05$ was considered statistically significant.

\section{Results}

\subsection{Characteristics of the Students}

A total of 1819 students, coming from 28 departments within the university, completed the survey. In the TS group, there were 300 (35.7\%) male and 541 (64.3\%) female students, and their age range was between 20 and 52 years (22.26 \pm 1.77 years), while the DEs consisted of 319 (32.6\%) male and 659 (67.4\%) female students aged from 19 to 43 years $(21.10 \pm 1.89$ years $)$.

Table 1 presents the comparison of the two groups of students on the study variables. The TSs were significantly older than the DEs, used more surface learning approaches, had stronger perceptions of the disparities in resources and stigma and academic study, were less satisfied with institutional attributes, had higher workload stress, and had more depression and less peer support, self-efficacy, active coping, and general support and advice. As a consequence, the TSs had a significant lower overall university experience satisfaction than the DEs.

\subsection{Correlations between Study Variables and Learning Approaches}

Tables 2-4 show the correlations between different study variables and learning approaches for all students, the TSs, and the DEs, respectively. For the TS group, the first five factors significantly positively correlated with DA were (in the descending order of $\mathrm{r}_{\mathrm{s}}$ ): self-efficacy, generic skills, alignment and constructive feedback, teaching for understanding, and encouraging learning and an active coping style. The first five factors for the DEs were: self-efficacy, generic skills, alignment and constructive feedback, teaching for understanding, and encouraging learning and peer support.

Furthermore, the first five factors significantly positively correlated with SA for the TSs were: study workload stress, avoidance coping style, academic study, resources and stigma and ALC. The first five factors for the DEs were: workload stress, avoidance coping style, escape coping style, resources and stigma, and academic study.

\subsection{Factors Predicting Learning Approaches}

Tables 5 and 6 show the factors affecting learning approaches. Self-efficacy was the strongest predictor of DA for all students $(\beta=0.340, p<0.001)$ and both the TSs $(\beta=0.329$, $p<0.001)$ and DEs $(\beta=0.385, p<0.001)$. Workload stress was ranked as the second or third predictor for all students and DEs, whereas alignment and constructive feedback was the second or third predictor for all students or TSs. Active coping style ranked as the third predictor for TSs, while generic skills ranked second for DEs.

For the SA, workload stress was the strongest predictor for all students $(\beta=0.225$, $p<0.001)$ and DEs $(\beta=0.283, p<0.001)$. However, it was the third predictor for TSs, while avoidance coping style was the strongest predictor of the SA for the TSs $(\beta=0.194$, $p<0.001)$. Perceived disparities in academic study were ranked second or third for all students and for the TS group, ALC was the second or third predictor for all students and for the DEs, while perceived disparities in resources and stigma was the second predictor for DEs. 
Table 1. Comparison of study variables between TSs and DEs.

\begin{tabular}{|c|c|c|c|}
\hline Factors & All Students $(n=1819)$ & TSs $(\mathrm{n}=841)$ & DEs $(n=978)$ \\
\hline Background factors & mean $\pm \mathrm{SD}$ & mean $\pm \mathrm{SD}$ & mean $\pm \mathrm{SD}$ \\
\hline Age $^{a}$ & $21.63 \pm 1.92$ & $22.26 \pm 1.77^{* * *}$ & $21.09 \pm 1.89$ \\
\hline cGPA & $3.10 \pm 0.38$ & $3.11 \pm 0.38$ & $3.10 \pm 0.38$ \\
\hline \multicolumn{4}{|c|}{ Teaching and learning environment (5-point Likert scale, mean of scores) } \\
\hline Teaching for understanding and encouraging learning ${ }^{a}$ & $3.61 \pm 0.58$ & $3.58 \pm 0.63$ & $3.64 \pm 0.54$ \\
\hline Peer support ${ }^{\mathrm{a}}$ & $3.79 \pm 0.64$ & $3.75 \pm 0.66$ & $3.83 \pm 0.62 * *$ \\
\hline Alignment and constructive feedback ${ }^{a}$ & $3.56 \pm 0.62$ & $3.53 \pm 0.63$ & $3.59 \pm 0.60$ \\
\hline \multicolumn{4}{|l|}{ Learning approaches (5-point Likert scale, mean of scores) } \\
\hline Deep approach ${ }^{a}$ & $3.54 \pm 0.51$ & $3.54 \pm 0.51$ & $3.54 \pm 0.50$ \\
\hline Surface approach ${ }^{\text {a }}$ & $3.17 \pm 0.62$ & $3.24 \pm 0.61 * * *$ & $3.12 \pm 0.62$ \\
\hline Self-efficacy ${ }^{a}$ & $3.54 \pm 0.65$ & $3.50 \pm 0.68$ & $3.58 \pm 0.61 *$ \\
\hline Workload stress $^{a}$ & $3.33 \pm 0.77$ & $3.45 \pm 0.77^{* * *}$ & $3.23 \pm 0.76$ \\
\hline Generic skills $^{a}$ & $3.67 \pm 0.59$ & $3.71 \pm 0.52$ & $3.71 \pm 0.52$ \\
\hline \multicolumn{4}{|c|}{ Perceived disparity: TSs vs. DEs (4-point Likert scale, mean of scores) } \\
\hline Resources and stigma $^{b}$ & $2.94 \pm 0.72$ & $3.03 \pm 0.73^{* * *}$ & $2.87 \pm 0.71$ \\
\hline Academic study ${ }^{b}$ & $3.17 \pm 0.77$ & $3.40 \pm 0.77^{* * *}$ & $2.97 \pm 0.71$ \\
\hline \multicolumn{4}{|l|}{ University support (4-point Likert scale, mean of scores) } \\
\hline General support and advising & $2.81 \pm 0.53$ & $2.75 \pm 0.54$ & $2.86 \pm 0.53^{* * *}$ \\
\hline Academic experience and advising & $2.87 \pm 0.54$ & $2.84 \pm 0.54$ & $2.90 \pm 0.53$ \\
\hline Institutional attributes & $2.88 \pm 0.51$ & $2.85 \pm 0.52$ & $2.91 \pm 0.50 *$ \\
\hline $\begin{array}{l}\text { Overall university experience satisfaction (4-point } \\
\text { Likert scale) }\end{array}$ & $2.94 \pm 0.61$ & $2.88 \pm 0.65$ & $3.00 \pm 0.57$ * \\
\hline \multicolumn{4}{|l|}{ Coping style (4-point Likert scale, mean of scores) } \\
\hline Avoidance $^{b}$ & $2.74 \pm 0.83$ & $2.73 \pm 0.83$ & $2.74 \pm 0.83$ \\
\hline Emotional $^{b}$ & $3.10 \pm 0.72$ & $3.07 \pm 0.72$ & $3.12 \pm 0.72$ \\
\hline Active $^{b}$ & $3.53 \pm 0.55$ & $3.50 \pm 0.56$ & $3.55 \pm 0.53 *$ \\
\hline Escape $^{\text {b }}$ & $2.78 \pm 0.79$ & $2.78 \pm 0.78$ & $2.78 \pm 0.80$ \\
\hline \multicolumn{4}{|l|}{ DASS (4-point Likert scale, sum of scores) } \\
\hline Depression & $11.89 \pm 9.56$ & $12.62 \pm 9.99 *$ & $11.27 \pm 9.13$ \\
\hline Anxiety & $11.26 \pm 9.06$ & $11.80 \pm 9.58$ & $10.80 \pm 8.55$ \\
\hline Stress & $14.91 \pm 9.82$ & $15.44 \pm 10.24$ & $14.45 \pm 9.42$ \\
\hline ALC (2-point Likert scale, sum of rescaled scores) & $12.00 \pm 3.43$ & $11.99 \pm 3.48$ & $12.01 \pm 3.38$ \\
\hline
\end{tabular}


Table 2. Correlation between study variables and learning approaches for all students.

\begin{tabular}{|c|c|c|c|c|c|c|c|c|c|c|c|c|c|c|c|c|c|c|c|c|c|c|c|c|}
\hline \multicolumn{2}{|c|}{ All students } & 1 & 2 & 3 & 4 & 5 & 6 & 7 & 8 & 9 & 10 & 11 & 12 & 13 & 14 & 15 & 16 & 17 & 18 & 19 & 20 & 21 & 22 & 23 \\
\hline 1 & $\begin{array}{l}\text { Deep } \\
\text { approach }\end{array}$ & 1 & & & & & & & & & & & & & & & & & & & & & & \\
\hline 2 & $\begin{array}{l}\text { Surface } \\
\text { approach }\end{array}$ & $0.196 * * *+$ & 1 & & & & & & & & & & & & & & & & & & & & & \\
\hline 3 & Age & 0.008 & 0.005 & 1 & & & & & & & & & & & & & & & & & & & & \\
\hline 5 & $\begin{array}{l}\text { Teaching for } \\
\text { understanding } \\
\text { \& encouraging } \\
\text { learning }\end{array}$ & $0.502^{* * * *}$ & $-0.056 *$ & -0.005 & $0.149 * * *$ & 1 & & & & & & & & & & & & & & & & & & \\
\hline 6 & \begin{tabular}{|l|} 
Peer support \\
\end{tabular} & $0.420 * * * *$ & -0.018 & -0.043 & $0.108 * * *$ & $0.584^{* * *+}$ & 1 & & & & & & & & & & & & & & & & & \\
\hline 7 & $\begin{array}{l}\text { Alignment \& } \\
\text { constructive } \\
\text { feedback }\end{array}$ & $0.511^{* * *}$ & 0.001 & -0.032 & 0.112 & $0.748^{* * * *}$ & $0.569^{* \text { *n+ }}$ & 1 & & & & & & & & & & & & & & & & \\
\hline 8 & Self-efficacy & $0.613^{* * * *}$ & -0.006 & 0.002 & $0.218^{* * *+}$ & $0.521^{* *+*}$ & 0.378 **t & $0.501^{* * *+*}$ & 1 & & & & & & & & & & & & & & & \\
\hline 9 & $\begin{array}{l}\text { Workload } \\
\text { stress }\end{array}$ & $0.170^{* * *}$ & $0.325^{* * *+}$ & $0.064^{* *}$ & 0.032 & -0.038 & -0.037 & $-0.059 *$ & 0.04 & 1 & & & & & & & & & & & & & & \\
\hline 10 & Generic skills & $0.546^{* * * *}$ & -0.024 & 0.004 & $0.123^{* * *}$ & $0.574^{* *+*}$ & $0.482^{* * * *}$ & $0.550^{* * * *}$ & 0.551 **** & 0.071 ** & 1 & & & & & & & & & & & & & \\
\hline 11 & $\begin{array}{l}\text { Resources and } \\
\text { stigma }\end{array}$ & $0.092 * * *+$ & $0.291 * * *$ & 0.029 & -0.042 & 0.033 & -0.035 & 0.042 & 0.054 * & $0.237^{* *+*}$ & 0.007 & 1 & & & & & & & & & & & & \\
\hline 12 & $\begin{array}{l}\text { Academic } \\
\text { study }\end{array}$ & $0.076^{* *}$ & $0.305^{* *+*}$ & $0.119^{* * *}$ & $-0.052 *$ & -0.013 & -0.031 & 0.008 & 0.058 * & $0.280^{*+*+}$ & 0.038 & $0.578^{* * * *}$ & 1 & & & & & & & & & & & \\
\hline 13 & $\begin{array}{l}\text { General } \\
\text { support and } \\
\text { advising }\end{array}$ & 0.224 *** & -0.020 & $-0.082 * * *$ & 0.015 & $0.334^{* * * *+}$ & $0.199 * * *+$ & $0.360^{* * * *}$ & $0.240^{* * *+}$ & -0.124 & $0.287^{* * * * *}$ & $0.080^{* *}$ & -0.015 & 1 & & & & & & & & & & \\
\hline 14 & $\begin{array}{l}\text { Academic } \\
\text { experience } \\
\text { and advising }\end{array}$ & $0.261^{* * * *}$ & -0.023 & -0.042 & 0.021 & $0.430^{* N+*}$ & $0.261^{* * * *+}$ & $0.433^{* * * *}$ & 0.275 *** & $\frac{-0.100}{x+x}$ & $0.335 * * *$ & $0.070^{* * *}$ & 0.024 & $0.654^{\text {w** }}$ & 1 & & & & & & & & & \\
\hline 16 & $\begin{array}{l}\text { Coping: } \\
\text { avoidance }\end{array}$ & -0.006 & $0.312^{* * *+}$ & -0.004 & $-0.097 * * *$ & -0.010 & $\frac{-0.105}{* * *}$ & 0.025 & -0.011 & $0.182^{* * *+}$ & ${ }_{* 0 *}^{-0.081}$ & $0.346^{* * * *}$ & $0.222 * * *$ & $0.126^{* *+*}$ & $0.116^{* * * *}$ & $0.072 * *$ & 1 & & & & & & & \\
\hline 17 & $\begin{array}{l}\text { Coping: } \\
\text { emotional }\end{array}$ & $0.074^{* *}$ & $0.232^{* * * *}$ & -0.024 & -0.037 & 0.035 & 0.033 & 0.045 & $0.060 *$ & $0.237^{* *+*}$ & 0.033 & 0.216 ***⿰ & $0.186^{* *+*}$ & $0.081 *$ & $0.074^{* *}$ & $0.093 * * *$ & $0.472 *$ & 1 & & & & & & \\
\hline 18 & Coping: active & $0.424 * * *$ & -0.017 & -0.021 & $0.099 * * *$ & $0.420^{* *+*}$ & $0.408^{* *+4}$ & $0.398 * * *$ & 0.411 **** & -0.004 & $0.501 * * *$ & -0.006 & 0.037 & 0.231 ****t & $0.291 * * *$ & $0.276^{* * * *}$ & -0.024 & $0.240^{* * *+4}$ & 1 & & & & & \\
\hline 19 & $\begin{array}{l}\text { Coping: } \\
\text { escape }\end{array}$ & $-0.130 * * *$ & $0.272 * * *$ & -0.018 & $-0.160^{* * *}$ & $\frac{-0.123}{* * *}$ & $\frac{-0.138}{* * *}$ & $\begin{array}{l}-0.096 \\
* * *\end{array}$ & $\frac{-0.116}{* * *}$ & $0.125^{* *+}$ & $=0.154$ & $0.238^{* * * *}$ & $0.208^{* * * *}$ & 0.032 & 0.018 & 0.015 & 0.486 *w+ & $0.392 * * *$ & $\begin{array}{l}-0.085 \\
* * *\end{array}$ & 1 & & & & \\
\hline 20 & Depression & $-0.179 * * *$ & $0.222 * * *+$ & $0.047 *$ & $-0.068^{* *}$ & $\frac{-0.272}{x+x}$ & $=0.233$ & $\begin{array}{l}-0.229 \\
* * * *\end{array}$ & $\frac{-0.282}{x \neq *}$ & $0.243^{* *+4}$ & $\begin{array}{l}-0.239 \\
* x \neq 1\end{array}$ & $0.124^{* * * *}$ & $0.127 * * *+$ & $\underset{* * *}{-0.186}$ & $\underset{* * *}{-0.217}$ & $\begin{array}{l}-0.155 \\
* x \neq\end{array}$ & $0.191 * * *$ & $0.144^{* * *+}$ & $\underset{* * *}{-0.253}$ & $0.232 * * *$ & 1 & & & \\
\hline 21 & Anxiety & $-0.103^{* * * *}$ & $0.188^{* * *+}$ & 0.025 & $-0.056^{*}$ & $\begin{array}{l}-0.190 \\
x * * * 1\end{array}$ & $\frac{-0.208}{x \neq *}$ & $\frac{-0.179}{* * *}$ & $\frac{-0.211}{* * * x}$ & $0.244^{*+*+}$ & $\begin{array}{l}-0.195 \\
* * * 1\end{array}$ & $0.130 * * *$ & $0.113^{* * * *}$ & $\underset{* * * 1}{-0.150}$ & $\underset{* * *}{-0.159}$ & $\begin{array}{l}-0.135 \\
* x+1\end{array}$ & $0.1811^{* * *+}$ & $0.137^{* w+}$ & $\underset{x * 0.204}{-0.204}$ & $0.194 * * *$ & 0.836 **** & 1 & & \\
\hline 22 & Stress & $-0.076 * *$ & $0.178^{* * *+}$ & 0.04 & -0.022 & $=0.184$ & $\frac{-0.192}{x * *+1}$ & $\underset{* * * 1}{-0.182}$ & -0.173 & $0.303^{* * *+}$ & -0.148 & $0.092 * * *$ & $0.102^{* * *}$ & -0.181 & $\underset{* * *}{-0.188}$ & $\begin{array}{l}-0.144 \\
x+4\end{array}$ & $0.126^{* * *+}$ & $0.177 * * *+$ & $\underset{* * * 142}{-0.142}$ & $0.145^{* * *+}$ & $0.831^{* * * *}$ & $0.843^{* *+*}$ & 1 & \\
\hline 23 & ALC & $-0.087 * * *$ & $0.278 * * *$ & -0.020 & $-0.110^{* * *}$ & -0.105 & -0.123 & -0.073 & -0.083 & $0.169^{* * * *}$ & -0.115 & $0.216^{* * * *}$ & $0.170^{* * *}$ & -0.015 & -0.038 & $-0.055^{*}$ & $0.303^{* * 4+}$ & $0.173 * * *$ & $\begin{array}{l}-0.109 \\
* * * *\end{array}$ & $0.300^{* * * *}$ & $0.204^{* * * *}$ & $0.168^{* * * *}$ & $0.140^{* * * *}$ & 1 \\
\hline
\end{tabular}


Table 3. Correlation between study variables and learning approaches for TSs.

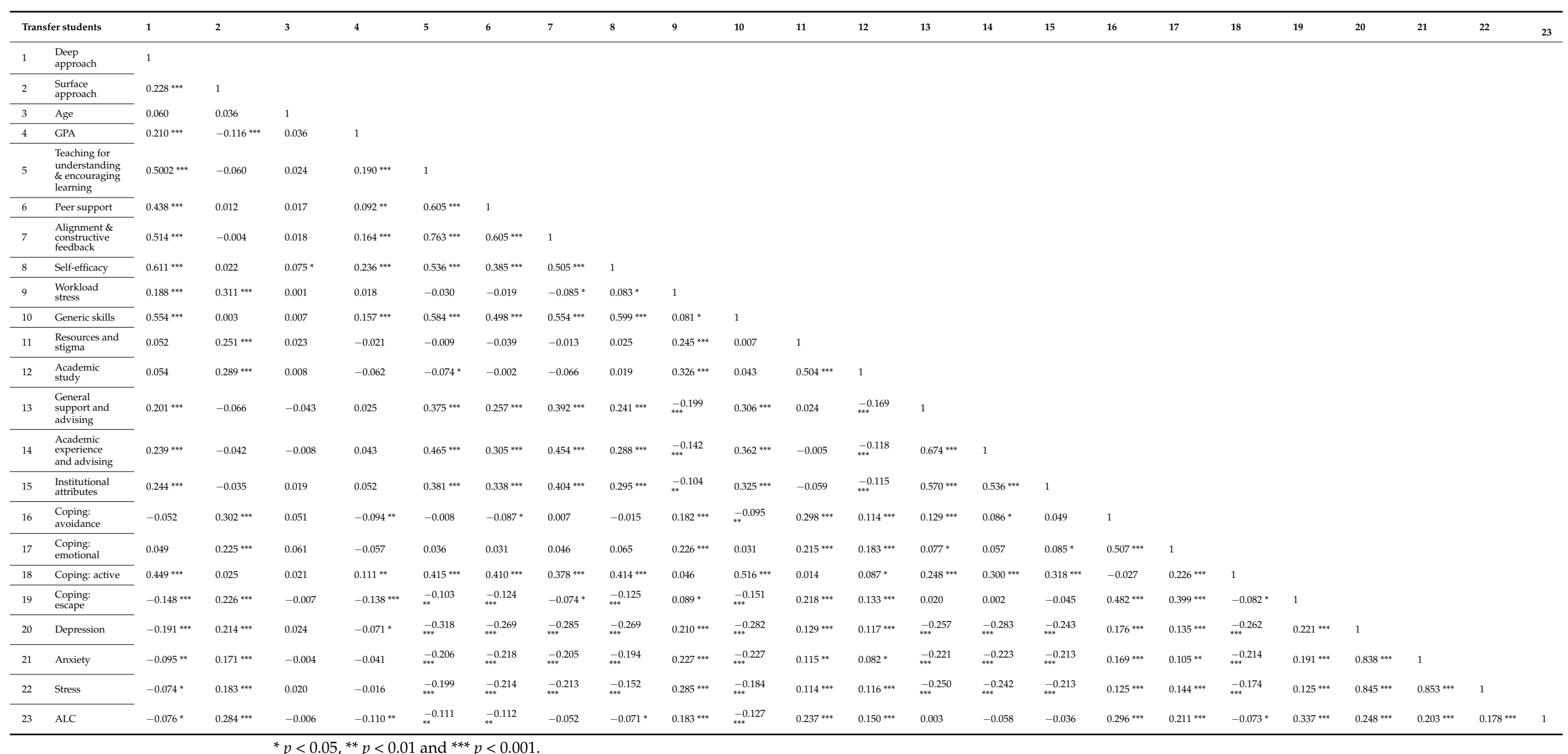


Table 4. Correlation between study variables and learning approaches for DEs.

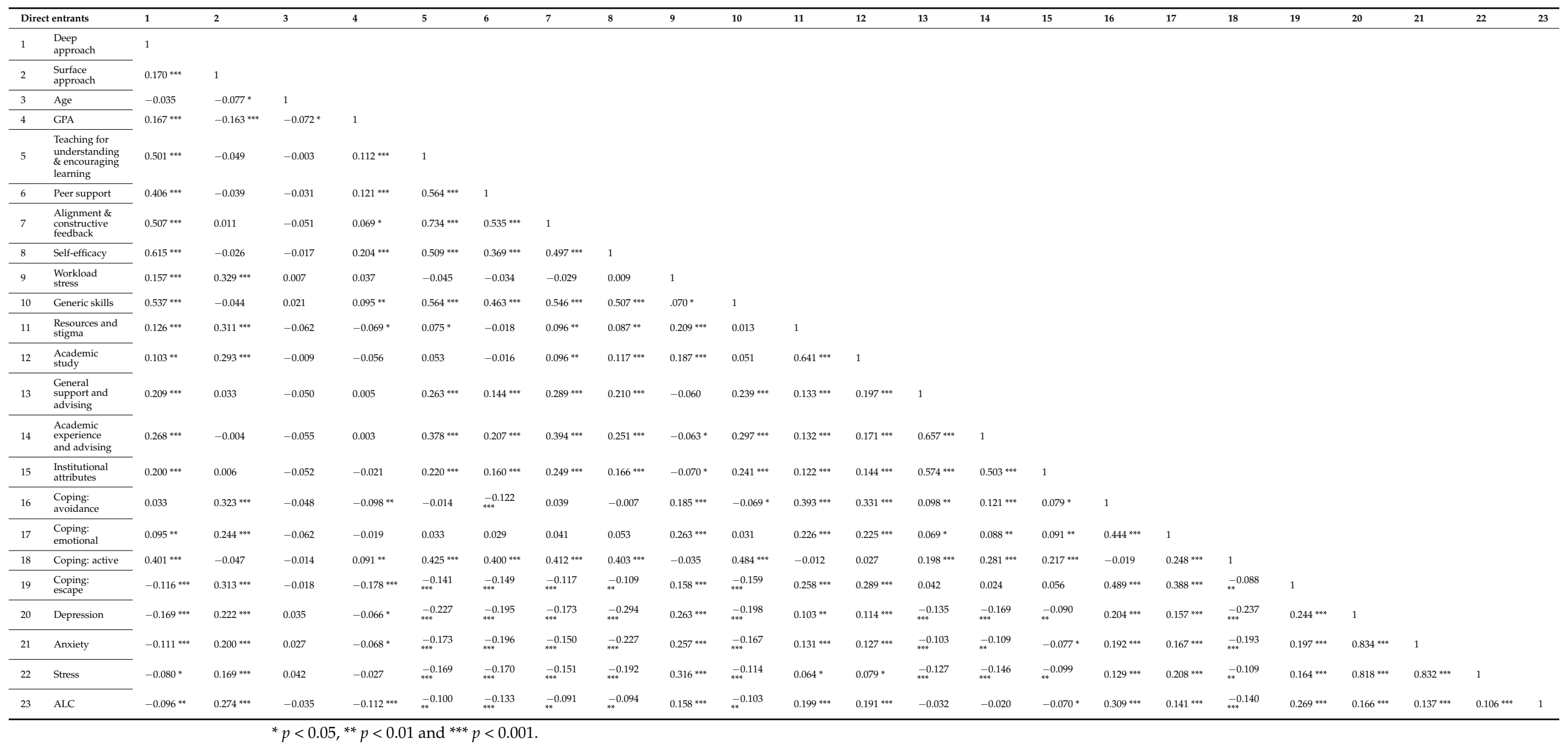


Table 5. Factors predicting a deep approach for all students, TSs, and DEs, according to the strength of the prediction.

\begin{tabular}{|c|c|c|c|}
\hline Regression & All Students & TSs & DEs \\
\hline $\mathrm{F}(\mathrm{df})$ & $199.26(9,1745)$ & $94.62(8,799)$ & $159.32(7,944)$ \\
\hline Adjusted $\mathrm{R}^{2}$ & 0.5043 & 0.4814 & 0.5382 \\
\hline$p$-value & $<0.001$ & $<0.001$ & $<0.001$ \\
\hline \multirow[t]{9}{*}{ Significant factor (s) } & $\begin{array}{l}\text { Self-efficacy } \\
(\beta=0.340, p<0.001)\end{array}$ & $\begin{array}{l}\text { Self-efficacy } \\
(\beta=0.329, p<0.001)\end{array}$ & $\begin{array}{l}\text { Self-efficacy } \\
(\beta=0.385, p<0.001)\end{array}$ \\
\hline & $\begin{array}{l}\text { Workload stress } \\
(\beta=0.195, p<0.001)\end{array}$ & $\begin{array}{l}\text { Alignment and constructive } \\
\text { feedback }(\beta=0.258, p<0.001)\end{array}$ & $\begin{array}{l}\text { Generic skills } \\
(\beta=0.209, p<0.001)\end{array}$ \\
\hline & $\begin{array}{l}\text { Alignment and constructive feedback } \\
(\beta=0.185, p<0.001)\end{array}$ & $\begin{array}{l}\text { Active } \\
(\beta=0.185, p<0.001)\end{array}$ & $\begin{array}{l}\text { Workload stress }(\beta=0.170, \\
p<0.001)\end{array}$ \\
\hline & $\begin{array}{l}\text { Active } \\
(\beta=0.129, p<0.001)\end{array}$ & $\begin{array}{l}\text { Workload stress } \\
(\beta=0.184, p<0.001)\end{array}$ & $\begin{array}{l}\text { Alignment and constructive } \\
\text { feedback }(\beta=0.145, p<0.001)\end{array}$ \\
\hline & $\begin{array}{l}\text { Generic skills } \\
(\beta=0.127, p<0.001)\end{array}$ & $\begin{array}{l}\text { Peer support } \\
(\beta=0.099, p=0.0037)\end{array}$ & $\begin{array}{l}\text { Peer support } \\
(\beta=0.115, p<0.001)\end{array}$ \\
\hline & $\begin{array}{l}\text { Peer support } \\
(\beta=0.105, p<0.001)\end{array}$ & $\begin{array}{l}\text { Escape } \\
(\beta=-0.099, p<0.001)\end{array}$ & $\begin{array}{l}\text { Hours of study (" } 1 \text { to } 5 \mathrm{~h} \text { " (ref) } \\
\text { vs. "more than } 5 \mathrm{~h} \text { ", } \beta=0.081 \text {, } \\
p<0.001 \text { ) }\end{array}$ \\
\hline & $\begin{array}{l}\text { Escape } \\
(\beta=-0.071, p<0.001)\end{array}$ & $\begin{array}{l}\text { Institutional attributes } \\
(\beta=-0.078, p=0.0075)\end{array}$ & $\begin{array}{l}\text { Institutional attributes } \\
(\beta=0.064, p=0.007)\end{array}$ \\
\hline & $\begin{array}{l}\text { Heard of Supporting Departments } \\
\text { ("know" (ref) vs. "don't know", } \\
\beta=0.063, p<0.001 \text { ) }\end{array}$ & $\begin{array}{l}\text { Hours of study (" } 1 \text { to } 5 \mathrm{~h} \text { " (ref) } \\
\text { vs. "more than } 5 \mathrm{~h}^{\prime}, \beta=0.074, \\
p=0.005)\end{array}$ & \\
\hline & $\begin{array}{l}\text { Social connections }(\beta=-0.060, \\
p=0.0035)\end{array}$ & & \\
\hline
\end{tabular}

Table 6. Factors predicting a surface approach for all students, TSs, and DEs, according to the strength of predication.

\begin{tabular}{|c|c|c|c|}
\hline Regression & All Students & TSs & DEs \\
\hline $\mathrm{F}(\mathrm{df})$ & $75.49(8,1749)$ & $42.38(6,810)$ & $57.67(6,920)$ \\
\hline Adjusted $\mathrm{R}^{2}$ & 0.2533 & 0.2333 & 0.2686 \\
\hline$p$-value & $<0.001$ & $<0.001$ & $<0.001$ \\
\hline \multirow[t]{8}{*}{ Significant factor (s) } & $\begin{array}{l}\text { Workload stress } \\
(\beta=0.225, p<0.001\end{array}$ & $\begin{array}{l}\text { Avoidance } \\
(\beta=0.194, p<0.001)\end{array}$ & $\begin{array}{l}\text { Workload stress } \\
(\beta=0.283, p<0.001)\end{array}$ \\
\hline & $\begin{array}{l}\text { ALC } \\
(\beta=0.130, p<0.001)\end{array}$ & $\begin{array}{l}\text { Academic study } \\
(\beta=0.188, p<0.001)\end{array}$ & $\begin{array}{l}\text { Resources and stigma }(\beta=0.191 \text {, } \\
p<0.001)\end{array}$ \\
\hline & $\begin{array}{l}\text { Academic study } \\
(\beta=0.120, p<0.001)\end{array}$ & $\begin{array}{l}\text { Workload stress }(\beta=0.155 \text {, } \\
p<0.001)\end{array}$ & $\operatorname{ALC}(\beta=0.145, p<0.001)$ \\
\hline & $\begin{array}{l}\text { Avoidance } \\
(\beta=0.119, p<0.001)\end{array}$ & $\begin{array}{l}\text { ALC } \\
(\beta=0.136, p<0.001)\end{array}$ & $\begin{array}{l}\text { Escape } \\
(\beta=0.144, p<0.001)\end{array}$ \\
\hline & $\begin{array}{l}\text { cGPA in university } \\
(\beta=-0.107, p<0.001)\end{array}$ & $\begin{array}{l}\text { Depression }(\beta=0.096 \\
p=0.0032)\end{array}$ & $\begin{array}{l}\text { cGPA in university } \\
(\beta=-0.124, p<0.001)\end{array}$ \\
\hline & $\begin{array}{l}\text { Resources and stigma } \\
(\beta=0.076, p=0.0056)\end{array}$ & $\begin{array}{l}\text { cGPA in university } \\
(\beta=-0.085, p=0.006)\end{array}$ & $\begin{array}{l}\text { Age } \\
(\beta=-0.103, p<0.001)\end{array}$ \\
\hline & $\begin{array}{l}\text { Depression ("normal to mild" } \\
\text { (ref) vs. "morderate to very } \\
\text { severe", } \beta=0.072, p<0.001 \text { ) }\end{array}$ & & \\
\hline & $\begin{array}{l}\text { Escape } \\
(\beta=0.071, p=0.004)\end{array}$ & & \\
\hline
\end{tabular}




\section{Discussion and Conclusion}

To our knowledge, this is the first study of its kind to investigate the differences between the learning approaches of TSs and DEs and the factors predicting these learning approaches, particularly in the Asian higher education context. Our findings reveal that TSs experience their learning environments as less favourable than DEs. Moreover, our findings partially supported the hypotheses, identifying some similar, and some different, predictors for TSs' and DEs' learning approaches.

\subsection{Differences in Learning Approaches of TSs and DEs}

Our findings show that the use of SA was significantly higher in the TSs, while the difference in the two groups' use of the deep and organized approach was not significant. Apparently, TSs tend to adopt more SAs (rote learning) along with DAs (deep understanding). This mixing of the two approaches has been observed previously in Chinese students [42]. Furthermore, Al Kadri et al. [43] and Rovers et al. [44] suggested that the choice of learning approach is affected by the time available and the workload. In Hong Kong, TSs are normally required to complete their degree studies in two years, with a strict " $2+2$ " pathway. However, due to the inadequate programme alignment between community college and university, they have heavier study loads than DEs [12,38,45]. Our study also found that TSs were exposed to less supportive learning environments. For instance, compared with DEs, they experienced higher study workload stress, less peer support, and less general support and advice. They also perceived higher disparities with regard to resources and stigma and academic study, felt less content with institutional attributes, such as the quality of university arrangements for students, used less active coping strategies, and had higher depression scores. Furthermore, lower self-efficacy could be another reason for TSs' use of SAs more than DEs. Bonsaksen, Sadeghi, and Thørrisen [34] found that students with low self-efficacy are more likely to adopt SAs and are more in favour of easy and simple assessments. As a consequence of all these unfavourable learning situations and constraints, TSs have no choice but to adopt SAs or switch between SAs and DAs; for instance, SAs are often used when students are overwhelmed with an excessive workload demand [33].

\subsection{Factors Predicting Students' Learning Approaches}

In our study, we identified similarities and differences in the factors predicting TSs' and DEs' learning approaches. We found that different coping styles were the significant predictors for both learning approaches. The effect of coping styles seems to particularly affect TSs: an active coping style was the third strongest predictor for the DAs, and an avoidance coping style ranked first and fourth in predicting SA use by the TSs and all students, respectively. Moneta, Spada, and Rost [46] found that an approach coping style was significantly correlated to DAs, whereas avoidance coping was correlated with SAs. While calling the idea "approach coping" (which is comparable to "active coping" in our study), these authors showed that students were solving problems actively and focusing directly on the source of the stress and problems [47]. This suggests that students with active (or approach) coping are able to face problems positively and seek solutions actively, to the extent that they are open to seeking help from others [48]. These students are more capable of understanding the knowledge they receive instead of relying on rote learning when coping with academic challenges [46]. Furthermore, Freire et al. [49] demonstrated that students with higher levels of self-efficacy are more flexible about using active coping strategies when under stress, and vice versa. TSs experienced lower self-efficacy as they had the stigma of perceiving themselves as "losers" and higher levels of stress by resorting to a "second chance" for university study after their CC study [50,51]. Such negative experiences can reduce the flexibility of their use of coping strategies. Therefore, this flexibility has the greater effect on TSs' learning approaches. 


\subsubsection{Deep Approach}

Self-efficacy was the strongest predictor affecting the adoption of DAs for TSs, DEs, and all students. This is aligned with previous results demonstrating that self-efficacy is significantly and positively correlated with DAs [46,52]. These researchers explained that students with higher self-efficacy tend to believe in their own abilities to handle and execute the tasks or to solve the problems they face, with their greater self-confidence motivating them to study and adopt higher-level learning [52].

Our data also showed that feedback (corresponding to "alignment and constructive feedback") is another of the top three predictors for DA adoption for TS, DEs, and overall for all students. Appropriate feedback can help students to understand what they have learnt and point out their strengths and weaknesses, in order to point them in the right direction and lead them to the most effective learning paths [53]. Although some studies (e.g., Gijbels et al. [54] found no significant impacts on modifying students' learning approaches, even with additional feedback, Hattie and Timperley [53] remarked that the effect of feedback in enhancing student learning is dependent on the level of the feedback. Educators should pay attention to giving feedback that aligns with the learning objectives to encourage students to modify their learning approaches appropriately.

Our findings indicated that generic skills were the third predictor of DA for the DEs and the fourth predictor for all students overall. The positive correlation between generic skills and the DA has been demonstrated previously $[31,55,56]$. Adopting DA requires generic skills such as applying knowledge, critical thinking, and analysing and structuring information [56]. Chan [57] found that curriculum-embedded initiatives (e.g., experiential learning and technological learning) are useful for helping students' development of generic skills in Hong Kong. In particular, our results indicated that generic skills do not affect TSs' adoption of DA in university study. This might suggest that their generic skills might have been developed and strengthened during their two-year study experience in CC, where many of their learning experiences help them to build a series of generic skills, such as research-based courses to enhance their critical thinking and analytical skills [58] and various co-curricular activities to improve their communication and interpersonal skills [59].

\subsubsection{Surface Approach}

Workload is an important variable to determine students' learning approaches [26]. In our results, the effect of the study workload stress was stronger on the SAs than on the DAs, and for DEs more than for TSs. It ranked first and third in predicting SA use for DEs/all students and TSs, respectively, and fourth in predicting DA use for all students, as well as for the TS and DE groups. It is understandable that an excessive workload may reduce students' learning motivation and morale and encourage the adoption of SAs in order to cope with excessive academic assessment without paying attention to the deeper educational purposes of their assignments [33]. There is also evidence reported in the literature that the effect of study workload stress may depend on the level of the stress and the individual's perception of it. Diseth [31] and Sun and Richardson [60] found that an appropriate level of workload is, in fact, positively correlated with the DA. On the other hand, a heavy workload or the perception that it is inappropriate can lead to more use of SAs and fewer DAs [31-33]. Thus, students who perceive their workloads to be suitable will be more encouraged to put effort into their studies and to apply their skills, eventually leading them to adopt DAs [52,55].

The perception of a disparity in learning support was found to be one of the top three predictors for SA adoption for both TSs and DEs. It was revealed that the TSs thought there was a great disparity between themselves and the DEs with regard to "resources and stigma" and "academic study", and they felt that they received less "general support and advice". These findings suggest that TSs have poorer self-perceptions due to the stigma of being "transfer students" and "losers in the public examinations" when they transfer from CC to university. TSs might see themselves as inferior to DEs and experience a higher level 
of academic stress [50]. As a matter of fact, students might swing between different learning approaches depending on their perceptions of the learning support they receive [43,61]. Thus, students with less learning support are more likely to shift to SAs.

Interestingly, GPA was the significant negative predicator for SA use for all students and both TSs and DEs. However, GPA was ranked as the weakest predictor for TSs, while DA did not seem to have a link with academic performance. This finding partially echoes the results of Trigwell, Ashwin, and Millan [52] that the SA has a strong negative impact on academic performance; it should be noted, however, that these authors also found the DA not to be correlated with academic performance. Surprisingly, we found that, although the TSs were more engaged with the SA, they had higher GPAs than the DEs [38]. This was not the first time that there have been deviations from the well-documented correlations between study approaches and GPA which have been observed in Chinese students in Hong Kong. Bonsaksen, Brown, Lim, and Fong [6] reported in their cross-cultural study that students from Hong Kong had higher scores for SA and GPA than students from the other countries, while their DA scores were similar. These, together, seem to suggest that the adoption of SAs does not directly imply a detrimental impact on students' GPAs. We speculated that the TSs might become skilful in adopting SAs to cope with academic assessment but that they are using DAs at the same time, and hence are not affected as much by the negative effects of the SAs. Similar findings from studies of Chinese students seem to support this speculation [42].

\subsection{Implications}

Our study demonstrated that some factors predicting learning approaches for TSs and DEs were similar and that some were different. Furthermore, the TSs perceived their learning environment to be less favourable than that of the DEs. Universities play an essential role in sustainable development education [1]. The commitment of education stakeholders in sustainable learning is inevitable. The results of our study indicate that university management, academic, and supporting staff should work collaboratively with the corresponding stakeholders in CC to tackle the needs of the TSs. The current one-sizefits-all strategy might not work appropriately to enhance the learning experiences of TSs. Their needs should be amplified to different levels in the university, CC, and even the government. In this study, the TSs had a higher tendency to adopt SAs, and had more issues with excessive study workload stress, stronger perceptions of disparities in their university studies, and higher levels of depression. TSs' coping styles have an important role in their adoption of learning approaches. Freire, Ferradás, Regueiro, Rodríguez, Valle, and Núñez [49] suggested that teachers could take initiatives and actions to foster students' self-regulation and executive functioning skills in order to encourage them to use appropriate coping styles when they are experiencing stress. Duration of study could be a critical factor that underlies stress and negative outcomes. TSs are only given two years to complete their university studies. Mirghani et al. [36] found that undergraduate students in a four-year programme frequently adopted SAs in the first two years and tended to change to DAs later in their senior years. This suggests that students, in general, require time to adjust to the new learning environment and settings at university. This is the same for TSs, who are required to complete university study within two years. They do not have enough time to adjust to using DAs, and maybe this is why the TSs in this study were observed to have a stronger tendency to use SAs to resolve academic challenges. This echoes Grove's [62] finding that students shifted towards SAs and used instrumental and goal-oriented approaches during their university studies to manage their heavy workloads at particular times. Seamless articulation from CC to university study should not only focus on academic credit transfer but also learning and social environments.

In fact, improving the university transfer system is a long journey that requires cooperation among numerous parties from CC, universities, and the government. These stakeholders should work together to modify the systems and policies of the transfer system [3]. Other modifications and enhancement aspects are also suggested for universi- 
ties to improve students' learning approaches, for instance, by improving their teaching styles and methods [26], enhancing their social interactions with academic staff [43], and providing language support (e.g., English) [63]. These modifications have been demonstrated to be effective in encouraging students towards the direction of adopting DAs in their study and learning. Furthermore, our findings indicate that some factors affecting the learning approaches used by TSs and DEs are similar, which suggests that the modifications and enhancements provided by university could also be beneficial to DEs. The predictors identified will be useful for education stakeholders to design teaching strategies or curricula to sustain the deep learning approach to meet the needs of both groups of students.

\subsection{Limitations}

In this study, data collection was conducted in only one university in Hong Kong, which could have reduced the generalizability of the current findings. This could be compensated for by using a larger sample with a wider coverage of different departments, faculties, and schools. In addition, in this study, there was a small portion of DEs (about $12 \%$ ) who had completed their sub-degrees and then entered directly to the first year of their four-year undergraduate programme. In fact, these DEs might have had similar study experiences as those of the TSs, as they had also come from the CC programme route. However, we did not distinguish them in our survey. These DEs may have used different learning approaches from those used by the normal DEs (without CC study experience). Apart from the CC programme, the participants may have come from different disciplines and programmes in the university. Students from different programmes might not have the same study patterns and learning approaches. In our future study, a discipline-based analysis will be conducted to further investigate the learning approaches between these two groups of students.

Author Contributions: Conceptualization, C.S.W.H. and K.C.; methodology, C.S.W.H., H.T. and K.C.; validation, K.C.; formal analysis, H.T.; investigation, C.S.W.H. and E.L.; resources, K.C.; data curation, K.C.; writing—original draft preparation, C.S.W.H.; writing-review and editing, E.L.; project administration, K.C.; funding acquisition, K.C. All authors have read and agreed to the published version of the manuscript.

Funding: This research was funded by the University Grant Committee (UGC) Funding Scheme for Teaching and Learning Related Proposals (2016-19 Triennium) (PolyU6/T\&L/16-19).

Institutional Review Board Statement: The study was conducted in accordance with the Declaration of Helsinki, and approved by the Ethics Committee of Human Subjects Ethics Sub-committee (protocol code HSEARS20180104005-01 and date of approval: 15 March 2018).

Informed Consent Statement: Informed consent was obtained from all subjects involved in the study.

Data Availability Statement: The data presented in this study are available on reasonable request from the corresponding author.

Acknowledgments: The authors are grateful to all the college transfer students for their participation in the study and the funding provided by University Grant Committee (UGC) Funding Scheme for Teaching and Learning Related Proposals (2016-19 Triennium) (PolyU6/T\&L/16-19).

Conflicts of Interest: The authors declare no conflict of interest. 


\section{Appendix A}

Table A1. Comparison between transfer students and direct entrants in learning approaches [12,37].

\begin{tabular}{|c|c|}
\hline \multicolumn{2}{|c|}{ Learning Approaches (12 Items) } \\
\hline \multicolumn{2}{|c|}{ Deep and organized approach (8 items) $(\alpha=0.84)$} \\
\hline 2 & I put a lot of effort into my studying \\
\hline 4 & On the whole, I've been systematic and organized in my studying \\
\hline 5 & Ideas I've come across in my academic reading set me off on long chains of thought \\
\hline 6 & I look at evidence carefully to reach my own conclusion about what I'm studying \\
\hline 8 & I organize my study time carefully to make the best use of it \\
\hline 10 & I carefully prioritize my time to make sure I can fit everything in \\
\hline 11 & I try to relate new material, as I am reading it, to what I already know on that topic \\
\hline 12 & I try to relate what I have learned in one subject to what I learn in other subjects \\
\hline \multicolumn{2}{|c|}{ Surface approach (4 items) $(\alpha=0.71)$} \\
\hline 1 & I've often had trouble making sense of the things I have to study \\
\hline 3 & Much of what I've learned seems no more than lots of unrelated bits and pieces in my mind \\
\hline 7 & Topics are presented in such complicated ways that I often can't see what they mean \\
\hline 9 & Often I have to study over and over things that don't really make much sense to me \\
\hline
\end{tabular}

Table A2. Comparison between transfer students and direct entrants in the teaching and learning environment [12,37].

\begin{tabular}{|c|c|}
\hline & and Learning Environment (21 Items) \\
\hline Tea & understanding and encouraging learning (11 items) $(\alpha=0.92)$ \\
\hline 1 & It is clear to me what I am expected to learn in subjects \\
\hline 2 & We are allowed some choices over what aspects of the subject to concentrate on in subjects \\
\hline 3 & What we are taught seems to match what we are supposed to learn \\
\hline 4 & I can see the relevance of most of what we are taught \\
\hline 5 & Subjects have given me a sense of what goes on "behind the scenes" in the subject area \\
\hline 6 & The teaching helps me to think about the evidence underpinning different views \\
\hline 7 & Teaching encourages me to relate what I learned to issues in a wider context \\
\hline 9 & I found most of what I learned in subjects really interesting \\
\hline 10 & Academic staff try to share their enthusiasm about the subject with us \\
\hline 12 & Academic staff are patient in explaining things which seem difficult to grasp \\
\hline 13 & I enjoyed participating in subjects \\
\hline 14 & Academic staff help us to see how we are supposed to think and reach conclusions in subjects \\
\hline Peet & $t(3$ items $)(\alpha=0.77)$ \\
\hline 8 & Students support each other and try to give help when it is needed \\
\hline 11 & Talking with other students helps me to develop my understanding \\
\hline 15 & I can generally work comfortably with other students \\
\hline Alic & and constructive feedback (7 items) $(\alpha=0.89)$ \\
\hline 16 & Subjects provide plenty of opportunities for me to discuss important ideas and topics \\
\hline 17 & I receive enough feedback about my learning (e.g., assignment work) \\
\hline 18 & It is clear to me what is expected in the assessed work (e.g., final examination) \\
\hline 19 & I can see how the subject assessment fits in with what I am supposed to learn \\
\hline 20 & The feedback given on my work helps me to improve my ways of learning and studying \\
\hline 21 & The subject assessment helps me to make connections to my existing knowledge or experience \\
\hline 22 & The feedback given on my subject assessments helps to clarify things I hadn't fully understood \\
\hline
\end{tabular}


Table A3. Comparison between transfer students and direct entrants in self-efficacy beliefs [12,37].

\begin{tabular}{ll}
\hline Self-Efficacy Beliefs (5 Items) $(\boldsymbol{\alpha}=\mathbf{0 . 8 6})$ \\
\hline 1 & I believe I will do well in my studies \\
\hline 2 & I'm certain I can understand the most difficult material in my studies \\
\hline 3 & I'm confident I can understand the basic concepts of my own study field \\
\hline 4 & I expect to do well in my studies \\
\hline 5 & I'm certain I can learn well the skills required in my study field \\
\hline
\end{tabular}

Table A4. Comparison between transfer students and direct entrants in the study workload [12,37].

\begin{tabular}{ll}
\hline Study Workload (3 Items) $(\boldsymbol{\alpha}=\mathbf{0 . 7 8})$ \\
\hline 1 & The workload of my studies is too heavy and causes too much study-related stress \\
\hline 2 & I put too much effort into my studies \\
\hline 3 & I am suffering from a high level of study-related stress \\
\hline
\end{tabular}

Table A5. Comparison between transfer students and direct entrants in general working life skills [12].

\begin{tabular}{ll}
\hline \multicolumn{2}{l}{ General Working Life Skills (7 Items) $(\boldsymbol{\alpha}=\mathbf{0 . 8 8})$} \\
\hline 1 & I have learnt to apply theoretical knowledge to practice \\
\hline 2 & I have learnt to develop cooperation and interpersonal skills \\
\hline 3 & I have learnt to analyze and categorize information \\
\hline 4 & I have learnt to see things from different points of view \\
\hline 5 & I have learnt to look at things critically \\
\hline 7 & I have learnt to make arguments and look for different solutions \\
\hline
\end{tabular}

Table A6. Comparison between transfer students and direct entrants in the perceived disparity of transfer students and direct entrants [39].

\begin{tabular}{|c|c|}
\hline & Disparity of Transfer Students and Direct Entrants (8 Items) \\
\hline Res & nd stigma (4 items) $(\alpha=0.80)$ \\
\hline 3 & There is a stigma at the University among students for having started at a sub-degree institution \\
\hline 4 & Most of PolyU support is designed for non-SYA students \\
\hline 5 & The resources to support non-SYA students are more than that for SYA students \\
\hline 6 & Academic staff provide more support to non-SYA students than SYA students \\
\hline Act & $\operatorname{tudy}(4$ items $)(\alpha=0.75)$ \\
\hline 7 & The study load for SYA students is much more than non-SYA students \\
\hline 8 & Non-SYA students have more opportunities to overseas exchanges than SYA students \\
\hline 9 & Generally, SYA students are more concerned about "getting the grade" instead of learning the material \\
\hline 10 & Many SYA students feel like they do not "fit in" on this campus \\
\hline
\end{tabular}


Table A7. Comparison between transfer students and direct entrants in the university support [39].

\begin{tabular}{|c|c|}
\hline \multicolumn{2}{|c|}{ University Support (20 Items) } \\
\hline \multicolumn{2}{|c|}{ General support and advising (10 items) $(\alpha=0.90)$} \\
\hline 11 & Work-integrated education (WIE) counselling and advising \\
\hline 12 & Support from WIE staff (e.g., hotel, hospital, business company, etc.) \\
\hline 13 & English support \\
\hline 14 & Foundation subjects support \\
\hline 15 & Overseas exchange opportunities and advising \\
\hline 16 & Career counseling and advising \\
\hline 17 & Psychological counselling and advising \\
\hline 18 & Financial counselling and advising \\
\hline 20 & Opportunities for community services \\
\hline 21 & Job placement services for students \\
\hline \multicolumn{2}{|c|}{ Academic experience and advising (6 items) $(\alpha=0.86)$} \\
\hline 5 & Sense of belonging at PolyU \\
\hline 6 & Academic advising \\
\hline 7 & Support from academic staff \\
\hline 8 & Support from non-academic staff \\
\hline 9 & Subject selection counselling and advising \\
\hline 10 & Subject registration counselling and advising \\
\hline \multicolumn{2}{|c|}{ Institutional attributes (4 items) $(\alpha=0.73)$} \\
\hline 22 & Class size \\
\hline 23 & Interaction with other SYA students \\
\hline 24 & Interaction with non-SYA students \\
\hline 25 & Leadership opportunities \\
\hline
\end{tabular}

Table A8. Comparison between transfer students and direct entrants in coping styles at the university [39].

\begin{tabular}{|c|c|}
\hline \multicolumn{2}{|c|}{ Coping Style at the University (15 Items) } \\
\hline \multicolumn{2}{|c|}{ Avoidance (3 items) $(\alpha=0.88)$} \\
\hline 7 & I refuse to believe that it happened \\
\hline 8 & I say to myself "this isn't real" \\
\hline 9 & I pretend that it hasn't really happened \\
\hline \multicolumn{2}{|c|}{ Emotional (3 items) $(\alpha=0.77)$} \\
\hline 10 & I let my feelings out when things don't go my way \\
\hline 11 & I feel a lot of emotional distress and I find myself expressing these feelings \\
\hline 12 & I get upset and let my emotions out \\
\hline \multicolumn{2}{|c|}{ Active (6 items) $(\alpha=0.81)$} \\
\hline 1 & I think about how I might best handle the problem \\
\hline 2 & I make a plan of action \\
\hline 3 & I try to come up with a strategy about what to do \\
\hline 4 & I think hard about what steps to take to resolve the problem \\
\hline 5 & I try to get emotional support from friends and family \\
\hline 6 & I discuss my feelings with someone \\
\hline \multicolumn{2}{|c|}{ Escape (3 items) $(\alpha=0.74)$} \\
\hline 13 & I skip class \\
\hline 14 & I reduce the amount of effort I put in to solve the problem \\
\hline 15 & I give up trying to reach my goal quickly and easily \\
\hline
\end{tabular}


Table A9. Comparison between transfer students and direct entrants in the Depression Anxiety Stress Scale (DASS) [40].

\section{DASS (21 Items)}

\section{Depression $(\alpha=0.89)$}

3 I couldn't seem to experience any positive feeling at all

5 I found it difficult to work up the initiative to do things

10 I felt that I had nothing to look forward to

13 I felt down-hearted and blue

16 I was unable to become enthusiastic about anything

17 I felt I wasn't worth much as a person

21 I felt that life was meaningless

Anxiety $(\alpha=0.88)$

2 I was aware of dryness of my mouth

4 I experienced breathing difficulty (e.g., excessively rapid breathing, breathlessness in the absence of physical exertion)

7 I experienced trembling (e.g., in the hands)

9 I was worried about situations in which I might panic and make a fool of myself

15 I felt I was close to panic

19 I was aware of the action of my heart in the absence of physical exertion (e.g., sense of heart rate increase, heart missing a beat)

20 I felt scared without good reason

Stress $(\alpha=0.89)$

1 I found it hard to wind down

$6 \quad$ I tend to over-react to situations

$8 \quad$ I felt that I was using a lot of nervous energy

11 I found myself getting agitated

12 I found it difficult to relax

14 I was intolerant of anything that kept me from getting on with what I was doing

18 I felt that I was rather touchy

Table A10. Comparison between transfer students and direct entrants in the academic locus of control [41].

\begin{tabular}{ll}
\hline \multicolumn{3}{l}{ Academic Locus of Control (18 Items) ( $\boldsymbol{\alpha}=\mathbf{0 . 7 2 )}$} \\
\hline 1 & I came to university because it was expected of me \\
\hline 2 & Some people have a knack for writing, while others can never write well no matter how hard they try \\
\hline 3 & At least once I have taken a course because it was an easy good grade \\
\hline 5 & Professors sometimes make an early impression of you and then no matter what you do, you cannot change that impression \\
\hline 6 & There are some subjects in which I could never do well \\
\hline 7 & I sometimes feel that there is nothing I can do to improve my situation \\
\hline 8 & There are many more important things for me than getting good grades \\
\hline 9 & For some courses it is not important to go to class \\
\hline 10 & Doing work on time is always important to me \\
\hline 11 & What I learn is more determined by university and course requirements than by what I want to learn \\
\hline 12 & I am easily distracted \\
\hline 13 & I can be easily taken out of studying \\
\hline 14 & I cannot accomplish what I need to do because I get depressed \\
\hline 15 & Things will probably go wrong for me some time in the near future \\
\hline 16 & I keep changing my mind about career goals \\
\hline 17 & There has been at least one instance in school where social activity impaired my academic performance \\
\hline 18 & I would like to graduate from university, but there are more important things in my life \\
\hline
\end{tabular}




\section{References}

1. Backman, M.; Pitt, H.; Marsden, T.; Mehmood, A.; Mathijs, E. Experiential approaches to sustainability education: Towards learning landscapes. Int. J. Sustain. High. Educ. 2019, 20, 139-156. [CrossRef]

2. Hoachlander, H.; Sikora, A.C.; Horn, L. Community College Students: Goals, Academic Preparation, and Outcomes Available online: $\quad$ https: / / www.google.com.hk/url?sa $=$ t\&rct=j\&q=\&esrc $=$ s\&source=web\&cd=\&cad=rja\&uact=8\&ved= 2ahUKEwiPgaeijJP2AhWrIbcAHVGhDVIQFnoECBIQAQ\&url=http\%3A\%2F\%2Fwww.gpo.gov\%2Ffdsys\%2Fpkg\%2FERICED482960\%2Fpdf\%2FERIC-ED482960.pdf\&usg=AOvVaw0jmq6yoa6ezRw43KIm5cp9 (accessed on 31 December 2003).

3. Flaga, C.T. The Process of Transition for Community College Transfer Students. Community Coll. J. Res. Pract. 2006, 30, 3-19. [CrossRef]

4. $\quad$ Shah, D.K.; Yadav, R.L.; Sharma, D.; Yadav, P.K.; Sapkota, N.K.; Jha, R.K.; Islam, M.N. Learning approach among health sciences students in a medical college in Nepal: A cross-sectional study. Adv. Med. Educ. Pract. 2016, 7, 137-143. [CrossRef] [PubMed]

5. Ullah, R. Learning environment, approaches to learning and learning preferences: Medical students versus general education students. JPMA J. Pak. Med. Assoc. 2016, 66, 541-544. [PubMed]

6. Bonsaksen, T.; Brown, T.; Lim, H.B.; Fong, K. Approaches to studying predict academic performance in undergraduate occupational therapy students: A cross-cultural study. BMC Med. Educ. 2017, 17, 76. [CrossRef] [PubMed]

7. Sakurai, Y.; Pyhältö, K.; Lindblom-Ylänne, S. Are Chinese university students more likely to exhibit a Surface approach to learning than other international students in Finland? J. Res. Int. Educ. 2014, 13, 135-148. [CrossRef]

8. Wawrzynski, M.R.; Sedlacek, M.R. Race and Gender Differences in the Transfer Student Experience. J. Coll. Stud. Dev. 2003, 44, 489-501. [CrossRef]

9. Walankar, P.P.; Panhale, V.P.; Situt, S.A. Evaluation of learning approaches in physiotherapy students: A valuable insight. J. Educ. Health Promot. 2019, 8, 25. [CrossRef]

10. Hills, J.R. Transfer Shock. J. Exp. Educ. 1965, 33, 201-215. [CrossRef]

11. Davies, T.G.; Casey, K. Transfer student experiences: Comparing their academic and social lives at the community college and university. Coll. Stud. J. 1999, 33, 60-71.

12. Cheung, K.; Yip, T.L.; Wan, C.L.J.; Tsang, H.; Zhang, L.W.; Parpala, A. Differences in study workload stress and its associated factors between transfer students and freshmen entrants in an Asian higher education context. PLoS ONE 2020, 15, e0233022. [CrossRef]

13. Eggleston, L.E.; Laanan, F.S. Making the transition to the senior institution. New Dir. Community Coll. 2001, 2001, 87-97. [CrossRef]

14. Kodama, C.M. Marginality of Transfer Commuter Students. NASPA J. 2002, 39, 233-250. [CrossRef]

15. Liu, C.H.; Stevens, C.; Wong, S.H.M.; Yasui, M.; Chen, J.A. The prevalence and predictors of mental health diagnoses and suicide among U.S. college students: Implications for addressing disparities in service use. Depress Anxiety 2019, 36, 8-17. [CrossRef] [PubMed]

16. Walker, C.; Sherman, J.; Shea, P. The Interstate Passport: A New Framework for Seamless Student Transfer. Change 2016, 48, 44-51. [CrossRef] [PubMed]

17. Mehr, K.E.; Daltry, R. Examining Mental Health Differences between Transfer and Nontransfer University Students Seeking Counseling Services. J. Coll. Stud. Psychother. 2016, 30, 146-155. [CrossRef]

18. Townsend, B.; Wilson, K. “A Hand Hold for A Little Bit”: Factors Facilitating the Success of Community College Transfer Students to a Large Research University. J. Coll. Stud. Dev. 2006, 47, 439-456. [CrossRef]

19. Wang, X.; Wharton, B. The Differential Patterns of College Involvement Between Transfer and Native Students. J. First-Year Exp. Stud. Transit. 2010, 22, 49-66.

20. Vermetten, Y.J.; Lodewijks, H.G.; Vermunt, J.D. Consistency and Variability of Learning Strategies in Different University Courses. High. Educ. 1999, 37, 1-21. [CrossRef]

21. Marton, F.; Säaljö, R. On qualitative differences in learning-II outcomes as a function of the learner's conception of the task. Br. J. Educ. Psychol. 1976, 46, 115-127. [CrossRef]

22. Marton, F.; Säaljö, R. On qualitative differences in learning-I outcome and process. Br. J. Educ. Psychol. 1976, 46, 4-11. [CrossRef]

23. Kanashiro, P.; Iizuka, E.S.; Sousa, C.; Dias, S.E.F. Sustainability in management education: A Biggs' 3P model application. Int. J. Sustain. High. Educ. 2020, 21, 671-684. [CrossRef]

24. Warburton, K. Deep learning and education for sustainability. Int. J. Sustain. High. Educ. 2003, 4, 44-56. [CrossRef]

25. Muñoz-García, A.; Villena-Martínez, M.D. Influences of Learning Approaches, Student Engagement, and Satisfaction with Learning on Measures of Sustainable Behavior in a Social Sciences Student Sample. Sustainability 2021, 13, 541. [CrossRef]

26. Baeten, M.; Kyndt, E.; Struyven, K.; Dochy, F. Using student-centred learning environments to stimulate deep approaches to learning: Factors encouraging or discouraging their effectiveness. Educ. Res. Rev. 2010, 5, 243-260. [CrossRef]

27. Vermunt, J.D. Relations between student learning patterns and personal andcontextual factors and academic performance. High Educ. 2005, 49, 205. [CrossRef]

28. Vermetten, Y.J.; Vermunt, J.D.; Lodewijks, H.G. A longitudinal perspective on learning strategies in higher education-different view-points towards development. Br. J. Educ. Psychol. 1999, 69, 221-242. [CrossRef]

29. Richardson, J.T.; Dawson, L.; Sadlo, G.; Jenkins, V.; McInnes, J. Perceived academic quality and approaches to studying in the health professions. Med. Teach. 2007, 29, e108-e116. [CrossRef] 
30. Cope, C.; Staehr, L. Improving students' learning approaches through intervention in an information systems learning environment. Stud. High. Educ. 2005, 30, 181-197. [CrossRef]

31. Diseth, Å. Approaches to learning, course experience and examination grade among undergraduate psychology students: Testing of mediator effects and construct validity. Stud. High. Educ. 2007, 32, 373-388. [CrossRef]

32. Diseth, Å.; Pallesen, S.; Hovland, A.; Larsen, S. Course experience, approaches to learning and academic achievement. Educ. Train. 2006, 48, 156-169. [CrossRef]

33. Kember, D. Interpreting student workload and the factors which shape students' perceptions of their workload. Stud. High. Educ. 2004, 29, 165-184. [CrossRef]

34. Bonsaksen, T.; Sadeghi, T.; Thørrisen, M.M. Associations Between Self-Esteem, General Self-Efficacy, and Approaches to Studying in Occupational Therapy Students: A Cross-Sectional Study. Occup. Ther. Ment. Health 2017, 33, 326-341. [CrossRef]

35. Rubin, M.; Scevak, J.; Southgate, E.; Macqueen, S.; Williams, P.; Douglas, H. Older women, deeper learning, and greater satisfaction at university: Age and gender predict university students' learning approach and degree satisfaction. J. Divers. High. Educ. 2018, 11, 82-96. [CrossRef]

36. Mirghani, H.; Ezimokhai, M.; Shaban, S.; van Berkel, H. Superficial and deep learning approaches among medical students in an interdisciplinary integrated curriculum. Educ. Health 2014, 27, 10-14. [CrossRef]

37. Parpala, A.; Lindblom-Ylänne, S. Using a research instrument for developing quality at the university. Qual. High. Educ. 2012, 18, 313-328. [CrossRef]

38. Cheung, K.; Chan, E.S.W.; Ng, J.; Tsang, H.; Leong, H.-V. Comparison of workload and academic performances of transfer and native students in an Asian educational context. High. Educ. Res. Dev. 2020, 1-15. [CrossRef]

39. Cheung, K.; Ng, J.; Tsang, H.; Pang, K.; Wan, C.; Moser, K. Factors Affecting Direct and Transfer Entrants' Active Coping and Satisfaction with the University. Int. J. Environ. Res. Public Health 2020, 17, 2803. [CrossRef]

40. Lovibond, P.F.; Lovibond, S.H. The structure of negative emotional states: Comparison of the Depression Anxiety Stress Scales (DASS) with the Beck Depression and Anxiety Inventories. Behav. Res. Ther. 1995, 33, 335-343. [CrossRef]

41. Trice, A.D. An Academic Locus of Control Scale for College Students. Percept. Mot. Skills. 1985, 61, 1043-1046. [CrossRef]

42. Watkins, D. Learning and Teaching: A cross-cultural perspective. Sch. Leadersh. Manag. 2000, 20, 161-173. [CrossRef]

43. Al Kadri, H.M.F.; Al-Moamary, M.S.; Elzubair, M.; Magzoub, M.E.; AlMutairi, A.; Roberts, C.; van der Vleuten, C. Exploring factors affecting undergraduate medical students' study strategies in the clinical years: A qualitative study. Adv. Health Sci. Educ. Theory Pract. 2011, 16, 553-567. [CrossRef]

44. Rovers, S.F.E.; Stalmeijer, R.E.; van Merriënboer, J.J.G.; Savelberg, H.H.C.M.; de Bruin, A.B.H. How and Why Do Students Use Learning Strategies? A Mixed Methods Study on Learning Strategies and Desirable Difficulties With Effective Strategy Users. Front. Psychol. 2018, 9, 2501. [CrossRef] [PubMed]

45. Ching, S.S.Y.; Zhang, L.W.; Guan, G.Y.; Cheung, K. Challenges of university nursing transfer students in an Asian context: A qualitative study. BMJ Open 2020, 10, e034205. [CrossRef] [PubMed]

46. Moneta, G.B.; Spada, M.M.; Rost, F.M. Approaches to studying when preparing for final exams as a function of coping strategies. Personal. Individ. Differ. 2007, 43, 191-202. [CrossRef]

47. Appelhans, B.; Schmeck, R.R. Learning styles and approach versus avoidant coping during academic exam preparation. Coll. Stud. J. 2002, 36, 157-160.

48. Shields, N. Stress, Active Coping, and Academic Performance Among Persisting and Nonpersisting College Students. J. Appl. Biobehav. Res. 2001, 6, 65-81. [CrossRef]

49. Freire, C.; Ferradás, M.D.M.; Regueiro, B.; Rodríguez, S.; Valle, A.; Núñez, J.C. Coping Strategies and Self-Efficacy in University Students: A Person-Centered Approach. Front. Psychol. 2020, 11, 841. [CrossRef] [PubMed]

50. Lee, W.W.S. Relationships among grit, academic performance, perceived academic failure, and stress in associate degree students J. Adolesc. 2017, 60, 148-152. [CrossRef]

51. Wong, Y.-L. Angels falling from grace? The rectification experiences of middle-class community-college students in Hong Kong. Stud. High. Educ. 2019, 44, 1303-1315. [CrossRef]

52. Trigwell, K.; Ashwin, P.; Millan, E.S. Evoked prior learning experience and approach to learning as predictors of academic achievement. Br. J. Educ. Psychol. 2013, 83, 363-378. [CrossRef]

53. Hattie, J.; Timperley, H. The Power of Feedback. Rev. Educ. Res. 2007, 77, 81-112. [CrossRef]

54. Gijbels, D.; Coertjens, L.; Vanthournout, G.; Struyf, E.; Van Petegem, P. Changing students' approaches to learning: A two-year study within a university teacher training course. Educ. Stud. 2009, 35, 503-513. [CrossRef]

55. Mørk, G.; Magne, T.A.; Carstensen, T.; Stigen, L.; Åsli, L.A.; Gramstad, A.; Johnson, S.G.; Bonsaksen, T. Associations between learning environment variables and students' approaches to studying: A cross-sectional study. BMC Med. Educ. 2020, 20, 120. [CrossRef] [PubMed]

56. Tuononen, T.; Parpala, A.; Lindblom-Ylänne, S. Complex interrelations between academic competences and students' approaches to learning-mixed-methods study. J. Furth. High. Educ. 2020, 44, 1080-1097. [CrossRef]

57. Chan, W.S.C. Students' understanding of generic skills development in a university in Hong Kong. Procedia-Soc. Behav. Sci. 2010, 2, 4815-4819. [CrossRef]

58. Kolokithas, A.; Calderón, O. A How-To Guide on Bringing Undergraduate Research to Community and Technical Colleges. J. Microbiol. Biol. Educ. 2018, 19, 19.3.99. [CrossRef] 
59. Hong Kong Community College. College Life: Student Development Activities. 2018. Available online: https://www.hkccpolyu.edu.hk/en/college-life/student-development-activities/index.html (accessed on 1 June 2020).

60. Sun, H.; Richardson, J.T.E. Students' perceptions of the academic environment and approaches to studying in British postgraduate business education. Assess. Eval. High. Educ. 2016, 41, 384-399. [CrossRef]

61. Richardson, J.T.E. Approaches to studying and perceptions of academic quality in a short web-based course. Br. J. Educ. Technol. 2003, 34, 433-442. [CrossRef]

62. Groves, M. Problem-Based Learning and Learning Approach: Is There a Relationship? Adv. Health Sci. Educ. 2005, 10, 315. [CrossRef]

63. Bobe, B.J.; Cooper, B.J. The effect of language proficiency on approaches to learning and satisfaction of undergraduate accounting students. Account. Educ. 2019, 28, 149-171. [CrossRef] 